\title{
What Influences Buying Leisure Services Coupons on Online Group Buying?
}

\author{
Neringa Langviniene, Jurgita Zemblyte, Gelmine Sliziene
}

\author{
Kaunas University of Technology \\ K. Donelaicio st. 73, LT-44029, Kaunas, Lithuania \\ E-mail.neringa.langviniene@ktu.lt,jurgita.zemblyte@ktu.lt,gelmine.sliziene@ktu.lt
}

cross $^{\text {ref }}$ http://dx.doi.org/10.5755/j01.ee.27.3.12944

\begin{abstract}
Growing use of IT, laptops, tablets, PC in individuals' life shaped an opportunity to create online group buying (OGB) as a new online business model. Several of surveys show that $O G B$ is rather popular for selling recreational activities and leisure services, such as restaurant coupons, cinema, spa, concert, flight tickets, museum visits, etc. Therefore, the paper aims to identify and estimate the influences that affect the customers to purchase the leisure services coupons on online group buying. Summarizing the significant findings in scientific literature, we identified six influences, namely price, trust, belonging to virtual community, system quality, information quality and service quality towards customers' intention to buy the leisure services coupons on group buying sites. The testing of these influences included two stages: focus groups interview and questionnaire. The data was collected from three focus groups and 81 customers - experts using OGB. Inconsistent with previous research results and our proposed hypotheses, the findings of research partly support the appropriateness of suggested influences for understanding customers' online group buying intentions. Results of the research show that price has the greatest impact on customers' intention to buy on group buying sites, while other influences have no significant effect. Besides, we identified positive relationships among customers' group buying experience (positive/negative), customers' purchase frequency in online group buying and intention to buy on group buying sites in the nearest future. Thus, customers on OGB are very oriented to price and use OGB for cost-saving reason.
\end{abstract}

Keywords: Influences, Intention to Buy, Leisure Services, Coupons, Online Group Buying (OGB), Customer.

\section{Introduction}

The boom of online group buying (OGB) started several decades before. Business persons found the advantage to sell their production through organizing the group sells, as well as the advantage to find more customers in shorter time and fewer attempts in advertising and promotion of the production (Fan et al., 2010). Chen (2012) and Cheng and Huang (2013) state that OGB is appreciated by the customers who hope to buy something cheaper, with large discount. Price is the major competitive advantage on OGB. Purchasing power of many clients enables to reduce the usual price of the product or services. Businesses use OGB as a channel for providing new service or product (Erdogmus \& Cicek, 2011). Thus, businesses benefit from bulk sales, short time between the advertisement and the distribution of products. Group buying sites serve as a communication channel for the customers, who identify themselves as members of virtual community (Yin \& Liu, 2012). This reduces the risk of buying a service from new OGB, increases the trust because of the possibility to share the information with other customers. A virtual community serves the provider with generated information about customers' demands, wishes, as well as serves as electronic word-of-mouth marketing about their production.

Researchers, who study the OGB (Fan et al., 2010; Cheng \& Huang, 2013; Langviniene \& Guobyte, 2014), usually distinguish the advantages as well as disadvantages of this way of sale, such as lack of trust from the customers, failures in services after purchasing coupons on OGB, etc. Personnel of the service provider complain about the overload after ending the sale of coupons, involuntary aggressive marketing trying to push the customer to buy additional services together with the services covered by coupon. Despite of the several disadvantages or threats brought by online coupons, the popularity of OGB is still growing and sellers should do the best at attracting the customers because of the rising competition among different e-shops, selling the same products and services, and among group buying sites (Cheng, Huang, 2013) and even traditional shops.

This paper aims to identify and estimate the influences on customers' intentions to buy the leisure services coupons on group buying sites.

Methods of the research: systematic and comparative analysis of literature; logical abstraction and conclusion generation methods; focus groups interview and questionnaire; statistical analysis methods.

\section{Online Group Buying in Leisure Services}

OGB is a new online business model, which started in the late 1990s in USA (Chen, 2012). The idea of such model is that shoppers with the same interests pool a group in order to buy product or service cheaper because of bulk purchasing. In return, sellers get large amount of customers in short time, use the group buying site as new communication platform, promote new service or product, shape new or larger segment of their customers. Group buying sites may help generate sales faster than selling services individually.

Research interest in online purchasing intention grounded usually in motives of the customers to buy online, on dimensions of services offerings, having impacts on repeat purchase intentions (Abdul-Muhmin, 2011). Customers' 
intentions to buy online determine the strength of a customer's intention to carry out purchasing behaviour (Ling et al., 2010). Online purchase intention is situation when purchaser is willing and intends to become involved in online transaction. As prices for the products or services sold online usually are lower, the profit from trade online is got because of large amount of customers, repeat purchasing, etc.

Choice for online purchasing is impacted by online shopping utility, customers perceived service risk and customers e-vendors qualities, such as attitude for risk, reputation (Azam \& Qiang, 2012). Usefulness and easy to use navigation are primary motives to use the website. Technology-based experience facilitates the use of the new site (Bagdoniene \& Zemblyte, 2009). Intention to purchase service online is directly related to the risk of service failure, financial risk, or risk because of personal data recording. Trust for service provider (privacy, system security, credit card fault, product risk), service quality parameters (tangibility, reliability, empathy, responsiveness, assurance), relative advantage (time saving, product value, easy to order, decreased transaction costs), online shopping experience (effort required to use a website, interactivity, fun of shopping) and perceived risk are perceived as characteristics of quality (Chang et al., 2005).

There are several online group buying advantages for customers. Primary advantage of the participating on OGB is a profit (Langviniene, Guobyte, 2014). They can negotiate the price and get large discount because of purchasing power what could the same compared to purchasing power of large retailers (Cheng \& Huang, 2013). When customer does not have enough information about the quality, price is a signal for the quality of service in other than group buying sites. Customers, joining the group, can affect the retailers and manufacturers on products characteristics and services (Chen, 2012). Individuals, who participate in a group, could act because of social motivation to be a member of virtual community. Purchasing decision, made by entire group, reduces the risk for the customer and grows the trust. Individuals can communicate in social networks, give them opinion, experience, advice (Yin \& Liu, 2012); show them competence that sometimes is very important social motive. In contrast to direct online shopping, OGB shopper enables a group to get a discount (Cheng \& Huang, 2013). Every customer is very important, as specific amount of services should be sold in order to get a discount. Thus, individuals feel themselves important and retailer evaluates them. Direct contact is usual among OGB customers that it is impossible in direct online buying (Gefen \& Straub, 2004; Mazaheri et al., 2012).

In addition, there are several disadvantages of OGB. Duration of action is limited in time. Impulsivity of the customers is more important on OGB, than in direct online shops, as many impulsivity-based decisions are made in rush (Parboteeah et al., 2009; Huang \& Kuo, 2012). Large risk is for trust in new group buying site, new retailer because of small price. As previous surveys show, customers, who pay less, expect larger value of the service and seem to blame themselves in services failure. Little attention of services providers using the online coupons after selling is paid. Uncertainty about transaction, payment system for the service is much higher than in direct online shops. The customer, who pays for product or service online, is not sure about personal information, card, payment transaction security and so on (Igleasias-Pradas et al., 2013). OGB customer is not sure to whom he or she pays: to intermediate, to OGB owner, or to final retailer, who sells his products here.

Several of surveys show that OGB is rather popular for selling recreational activities and services, such as restaurant coupons, cinema, spa, concert, plane tickets, museum visits, etc. (Erdogmus \& Cicek, 2011). OGB is a channel for new ideas, innovative products (Crespo \& Bosque, 2008). Discounted services attract customers, who have never used one or another service what is not of primary necessity. Browsing the group buying site is usually done during leisure time; break in working hours, drinking coffee, preparing for new day, etc. As Huang and Kuo (2012) research shows, many decisions on leisure services are done impulsive. The online shoppers are usually more adventurous and may seek for non-traditional purchasing methods, new technologies, new services offering (Swinyard \& Smith; 2011).

Collective purchasing in leisure services is very popular. Individuals with similar interests share the information where to go, what to use, what to try. Individuals with the same living, school, work environment, or even social networks overlap, are likely to be interested in the same leisure activity. Pronouncing the information about the leisure services coupons in social networking, individuals feel the sense of community in decision-making about purchasing, as they do not feel alone.

The coupons for leisure services could be sold both on group buying sites and in specialized e-shops. Why leisure service businesses use the online group buying sites for selling their services? Tourism, hospitality, catering services providers use the coupons for supporting the revenue and differential marketing strategies, for unsold services, for managing demand fluctuations (Sigala, 2013). Coupons could be used for reminding the potential customers about the leisure activity, enterprise, brand, to retain existing customers, stimulating to use new service or activity.

The services providers, wanting to promote or introduce their services to the market, sell online coupons, let say, at 90 percent of usual price. Online group buying sites introduce such deals every day sending e-mails to customers' database, other social networking tools. The customers gets discounts, if minimum required amount of coupons are shared and ordered. Otherwise action is cancelled and customers' credit card is not charged. So minimum amount of purchasing and delay in using the service - are common discomfort elements in purchasing the leisure services coupons.

The leisure services providers use online coupons as a way to manage situation of limited capacity (occupation of hotel, seats in plane). The provider can control, see the availability of coupons, collect comments by viewers and react to them, collect non-personal information, such as what websites visitors visit besides this group buying site and include information about search by individual. The providers can strengthen the promotion of their services targeting coupon campaigns. Customers can shorten time in seeking for subscribing to get news about specific services, such as travel and restaurant, etc. They can provide feedback for provider, become advocate of the firm. Sometimes the leisure services coupons act as marketing tool for new customers. If minimum coupons are not sold, there no advertising costs, but visitors of group buying site already know the service provider. The 
leisure services coupons reduce the risk for repeated purchasing as customer already knows the brand of the provider; it increases the loyalty of the customer.

\section{Research Model and Hypotheses}

As not each of group buying sites is equally successful in its profit and development, it is important to know what exactly influence the customers to buy here and to do it repeatedly. Intense competition means that OGB business depends on interactive, cost-efficient and attractive services, as well as attracting new and maintaining existing customers (Kim et al., 2012). Customer-oriented business on OGB, upto-date information and offerings including appreciated parameters of quality should be provided. Even if the same service is purchased, different group buying sites create different experience for their customers (Ling et al., 2010). There are several factors influencing the OGB shopper. Our model and hypotheses highlight six influences most commonly discussed in the "online group buying" literature.

The first influence is perception of lower price for product or service. This is common driver of OGB, as shopper hopes save money (Shiau \& Luo, 2012). Discount of a service or product should be obvious, comparing to the traditional trade. The price usually makes only the first step for entering the OGB site. Price has been long considered as key factor for online purchaser (Kim et al., 2012b), besides customer can quickly compare the prices of products online. Thus, we hypothesize that:

H1. Customers' perception of comparable lower price has significant influence on customers' intention to buy on group buying sites.

In the virtual community trust is another primary factor influencing to attend the OGB (Kim et al., 2012b; Cheng \& Huang, 2013). Customer attending the OGB expects cheaper price for a product or service either significant discount. Priority for price or trust depends on the experience of the customer to buy online, on OGB, or to buy known brand service or product. First-time user usually appreciates the trust for the seller, but experienced OGB customer pays more attention to the price and other parameters of the services, such as quality, responsiveness, brand, etc. Hence, we hypothesize that:

H2. Trust has significant influence on customers' intention to buy on group buying sites.

Belonging to virtual community influence the intentions to buy on OGB (Crespo \& Bosque, 2008). If individual provides advice, based on his experience, knowledge, he expects rewards in the future, regarding similar experience sharing of other customers, prevention about negative experience to prevent others, etc. (Munzel \& Kunz, 2014). Shiau and Luo (2012) study in behaviour of OGB shoppers confirmed that the price is not the only criterion for making decision about purchasing. Individuals try to obtain important information and prevent negative experience when they buy something very cheap. As sharing information among community members is valuable and helpful, it multiplies additional potential customers and increases their intention to purchase. Community member feels connection with other members, what becomes more important. The virtual community participation reduces the risk for customers and increases the trust for the retailers (Pai, Tsai, 2011). The retailers, as customers, can engage into dialogue with the customers and respond their worriment about the intention to buy the service. Members of community get advice how to use group buying site better, they are educated by each other, get support for making decision about the purchasing. Community members get information about interested service or product quicker than from retailer. Identifying himself / herself as a member of the community motivates the member to buy on OGB. Therefore, we formulate the following hypothesis:

H3. Belonging to virtual community has significant influence on customers' intention to buy on group buying sites.

Cheng and Huang (2013) suggest evaluating information quality, system quality, and service quality as main factors for intention to buy on OGB. System quality is described by website usability, availability, reliability, adaptability and response time. Online system must support purchasing activity by providing security and accessibility (Kim et al., 2012). Accessibility refers to sense of convenience to browse, leading to spend more time, and, finally, to purchase. As no direct contact with retailer on OGB usually is available, customer's intention to buy is influenced by web site easy use and navigation (Mazaheri, 2012). Therefore, we hypothesize that:

H4. System quality has significant influence on customers' intention to buy on group buying sites.

Information quality covers customer attitude to completeness, relevance and easy to understand contents of group buying site. Information quality relates to usefulness and timeliness of the information (timely information regarding the service, quite often updating of the information) (Corbitt et al., 2003). Customers use OGB not only for buying what they want but also for researching products or services (Kim et al., 2012). The newest information helps to make the best decision. Group buying site should always be quick in adopting new technologies, new marketing techniques. Thus, we hypothesize that:

H5. Information quality has significant influence on customers' intention to buy on group buying sites.

Service quality relates to customers feeling about assurance, empathy, and responsiveness in services of group buying site. Service quality refers to online and off-line elements (Kim et al., 2012). The online quality includes ordering, feedback, solving the customers' complaints, offline - delivery of services, acceptance of returns, etc. Surveys show (Harris et al., 2006) that OGB customers seemed to blame themselves in case of service failure more often. As they control the process of OGB coupons retailing, they do not expect service recovery if everything goes wrong. They perceive that they cannot blame the provider as no physical contact pushing to buy the coupon was. However, the findings of that survey showed that service quality does not significantly affect intentions to buy. It is very difficult to evaluate the quality of OGB for customers, who have never bought on OGB. It is not enough to evaluate the service quality for first-time users. Such quality parameters of website, information, etc., should be included. Findings by Corbitt, et al. (2003) showed that the better evaluation of quality of the service, the bigger trust for the provider was founded. One more thing should be mentioned - the evaluation of quality is a subject for change. As customers 
using the Internet, acquire the experience - technological, information seeking, navigation use, etc. - their priorities, evaluation of group buying site, service characteristics also can change. Criteria, what seems to be important, are not stable for OGB customers (Hernandez et al., 2010). Technological experience facilitates the acquisition of information, encourages the adoption of different IT, alters the initial expectations for the service and changes the intentions to purchase or not. Experience to be on Internet reduces the time for seeking information, eases the navigation inside the web, and making buying decision. Being more experienced and consuming more services after buying on OGB, customers re-evaluate their priorities, evaluation criteria. More experienced customers need less information for making a decision than inexperienced ones. In sum, we hypothesize:

H6. Service quality has significant influence on customers' intention to buy on group buying sites.

We also include age, gender, frequency of online group buying, online group buying experience, expenditure on online group buying and experience (positive/negative) on online group buying as control variables that might affect customers' intentions to buy on group buying sites.

Figure 1 presents the hypotheses derived from the literature and shows the relationships between influential factors and customers' intention to buy on group buying sites.

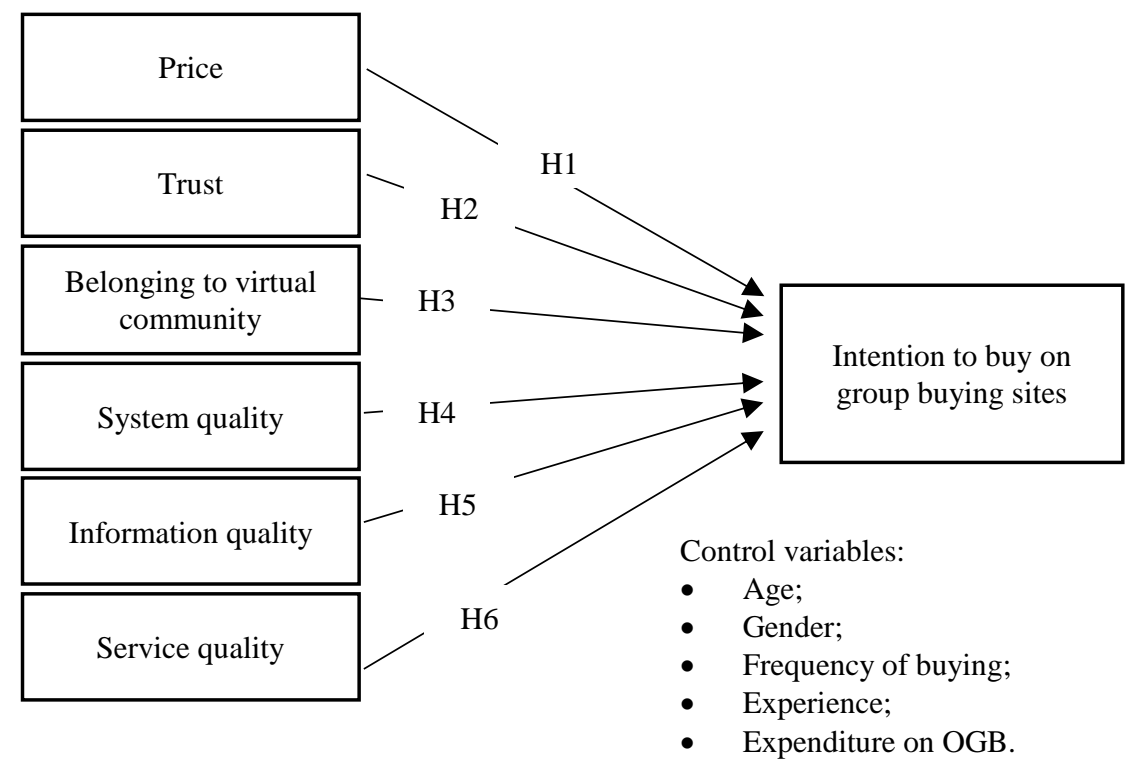

Figure 1. Conceptual model and hypothesized relationships

\section{Research Methodology}

The aim of research was to reveal the influences that affect customers' intentions to buy the leisure services coupons on OGB. The research by its nature is intended for better understanding of relationships between influential factors and customers' intention to buy on OGB. Thus, we developed exploratory research aimed to OGB shoppers in Lithuania.

\section{Sample and Data Collection}

The empirical research included two stages: focus groups interview and questionnaire. In the first stage, we carried out preliminary qualitative research, which consists of three focus groups of experts using OGB. The first focus group was formed of six students (both employed and not employed) between 19-25 years old. The second one was formed of five respondents between $26-35$, living in the family with or without small children. The third group consisted of four respondents were married women, 45-54 years old, whose children were adults already. All focus groups were formed in March 2015. We adopted the focus group interview that is well suited to exploratory investigations where aim is better understanding of phenomenon. Given the scope of the paper, we asked the experts in focus groups about influential factors on decision to buy the leisure services coupons on OGB. The information gained from focus groups helped us to shape questionnaire for current OGB shoppers, to analyse and interpret the results of the quantitative survey.

The convenience quota sampling was adopted for the second stage of this research. According to statistic (Informacines visuomenes statistika. Namu ukiai ir asmenys, 2015), $74 \%$ of Lithuanian people used the Internet during last three quarters, $50 \%$ of them used the Internet for ordering services or goods online. More than half of shoppers buy services or goods online more than once a year according that statistics. Totally, $49 \%$ of Lithuanian people, who bought services or goods online, were 16-29 - year-old (Community survey on ICT usage in households and by individuals, 2015). Accordingly, students represent this population and might be used as sample. Todays' students represent current and future targets for OGB as their higher education can be expected to generate high income, making future online buying more likely.

In totally 445 students were selected from those who attended university courses delivered by the paper authors as respondents in April 2015. A voluntary participative approach was applied. In the questionnaire survey, we explained to students face-to-face and asked to complete a questionnaire if they buy the leisure services coupons on group buying sites. The students, who indicated their willingness to participate, were given the questionnaire. A few students were willing to distribute the questionnaire to other colleagues (not students), who have experience on 
group buying sites. The response rate was $23 \%$. The final sample consisted of 103 questionnaires (81 were valid). Hence, this is an exploratory study and we will focus on examining relationships between influential factors and customers' intention to buy the leisure services coupons on OGB or not, instead of generalization of the results.

The data was analysed using SPSS 20.0 software.

The leisure services coupons supply on Lithuanian group buying sites

\begin{tabular}{|c|c|c|c|c|c|c|c|c|c|c|c|c|}
\hline Services, belonging to leisure & 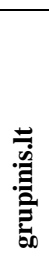 & 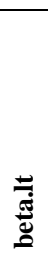 & 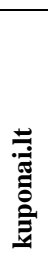 & 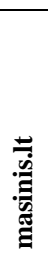 & 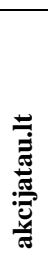 & 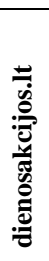 & 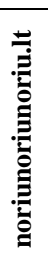 & 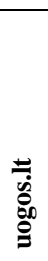 & 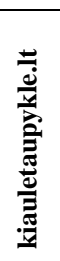 & 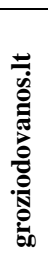 & 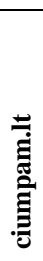 & 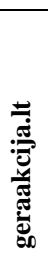 \\
\hline Beauty services & $*$ & $*$ & $*$ & $*$ & & $*$ & * & $*$ & $*$ & $*$ & $*$ & $*$ \\
\hline Accommodation services & $*$ & $*$ & $*$ & $*$ & $*$ & $*$ & $*$ & $*$ & & & & \\
\hline Recreation and wellness services & $*$ & $*$ & $*$ & $*$ & & * & * & & & $*$ & & \\
\hline Travel services & $*$ & $*$ & * & * & $*$ & & & $*$ & & & & \\
\hline Adventure leisure services & $*$ & * & $*$ & $*$ & $*$ & & & & & & & \\
\hline Food serving services & $*$ & * & & & * & * & & $*$ & & & & \\
\hline Sports and physical recreation services & $*$ & $*$ & $*$ & $*$ & $*$ & & & & & & & \\
\hline Culture events and activities services & $*$ & * & * & & & & & & & & $*$ & \\
\hline Amusement and theme parks service & * & * & * & & & & * & & & & & \\
\hline Courses and training & * & & & & * & & & & * & & & \\
\hline Nightclubs, discos & $*$ & & $*$ & $*$ & & & & & & & & \\
\hline Children's games and entertainment services & & & & * & * & & & & & & & \\
\hline Camping services & & & & & & * & & & & & & \\
\hline
\end{tabular}

Note: * Group buying site offered the leisure services coupons within 2015 year.

\section{Measures}

First, we did the general overview of group buying sites and leisure service offerings. The list of leisure services was used according to categorization of leisure services, used during leisure time (Langviniene, 2013). Penetration of internet in Lithuania is similar to the average of the EU. There are one million internet users in Lithuania. However, purchasing online is done approximately by $20 \%$ of population. OGB as a way for selling services and products is known in Lithuania from 2010. Customers have 34 group buying sites at their disposal in Lithuania. There, they can buy coupons for products and services that are offered with a discount of $50 \%$ to $94 \%$ of their regular price. About $75 \%$ of OGB shoppers are women. The revenue of online group buying reaches 20-23 million Euros per year. Group buying sites operate at 15-30\% margin. On the contrary to European countries in which global giant Groupon is market leader, local companies - beta.lt and grupinis.lt - are dominating. They collect about $90 \%$ of all online group buying revenues. Lithuanian group buying sites usually provide many offers of leisure services; in the sites even is exceptional category for leisure services. Table 1 presents the biggest group buying sites and the leisure services coupons variety within 2015 .

Second, according to literature analysis and focus groups results, we prepared the questionnaire. The questionnaire consisted of three parts, i.e. Part 1: asking about the use of OGB and leisure service coupons buying history, Part 2: asking about the influences of customers' intention to buy the leisure services coupons on OGB, and Part 3: questions about demographic data. All questions required the respondents to rate items based on a five-point Likert-type scales from 1 to 5 (from strongly disagree to strongly agree). The initial version of the questionnaire was pre-tested by three experienced customers and researchers in the university and four experienced shoppers of the leisure services coupons on
OGB. Design of the questionnaire was modified according to their feedback. The appendix shows the questionnaire items that reflect the following influential factors: price, trust, belonging to virtual community, system quality, information quality and service quality.

\section{Results of Focus Groups}

The results of the focus groups are presented in Table 2. Younger respondents are more regular customers on group buying sites. Younger respondents of the first focus group were purchasing once per month, the older ones of the third group - only once-twice per year.

The participants of the focus groups ground their intention to buy online on the popularity of group buying sites, their reputation. Besides, they try to buy something new, innovative in less known online group buying sites because of new service offerings. The respondents mentioned that they bought services for leisure because they knew already what to expect, for example, buying weekend in the resort. The older respondents do not like to use online banking. Thus, they prefer to buy services traditionally or from OGB provider office in the retail stores. The respondents of all groups were asked about the main reasons, why they purchase on OGB. Most of them mentioned large discounts and low prices. Convenience to use, availability to use it at home, and only several clicks on a computer mouse were mentioned as well. Most respondents stated that one of the factors, which influence to buy the leisure services coupons, is delayed use of a coupon as they can plan their vocation. The intention to buy the leisure service coupon is strengthened by the guarantee of returning money in case of the service failure. The members of Facebook share the information about new services. Furthermore, recommendations by their friends look more trustable. Customers have some fears about using the leisure services coupons on OGB. One of them is negative 
attitude to the customer, who buys service cheaper on OGB than traditional customers do. Besides, the quality of services sometimes does not satisfy the expectations as service companies are overcrowded. The informants of the focus groups indicated that they were served only after the customers, who buy leisure services directly from service organization.
Summing up, the price is very important for the intention to buy the leisure services coupons on OGB. Customers trust the service organization, group buying site were stated as well. Moreover, customers feel more confident and make purchase decisions easier when they participate in virtual community. Fewer discussions were about group buying sites information, system quality and service quality.

Table 2

The influences affecting customers' intentions to buy on OGB

\begin{tabular}{|c|c|c|}
\hline Category & Sub-category & Confirming affirmation \\
\hline \multirow{2}{*}{ Price } & Low price & $\begin{array}{l}\text { "... I will save a lot here...”, “... main motive is small price...”, “... the most urgent factor is low } \\
\text { price...", "...I see small price and..." }\end{array}$ \\
\hline & Significant discount & $\begin{array}{l}\text { "... large discounts”, “... with significant discount”, “...percentage discount is huge...”, “...large } \\
\text { discounts could be obtained ...", “... additional free services motive me..." }\end{array}$ \\
\hline \multirow[t]{2}{*}{ Trust } & To retailer/brand & $\begin{array}{l}\text { ".. I am afraid about the quality...”, “... service providers look offhandedly if you use service by } \\
\text { coupon ...”, "... the price was only for main dish, I should buy vegetables myself...”, "clients, who } \\
\text { bought service directly, were served before me..." }\end{array}$ \\
\hline & $\begin{array}{l}\text { To provider/ Group } \\
\text { buying site }\end{array}$ & $\begin{array}{l}\text { "if I buy, only in well know sites, such as...", "majority of my friends buy here", "not many time before I } \\
\text { have bought service in poor known website because I have nothing interesting found in ..." }\end{array}$ \\
\hline \multirow{2}{*}{$\begin{array}{l}\text { Belonging to } \\
\text { virtual community }\end{array}$} & $\begin{array}{l}\text { Direct membership in } \\
\text { group }\end{array}$ & "... reading what my Facebook friends do give me more idea..." \\
\hline & $\begin{array}{l}\text { Communication } \\
\text { through special } \\
\text { networks }\end{array}$ & $\begin{array}{l}\text { “... comments of my friend motive me...”, “... he recommend it to me...”, “.. sometimes banners in } \\
\text { Facebook motive me to see offer more detail...” }\end{array}$ \\
\hline \multirow{3}{*}{$\begin{array}{l}\text { Information } \\
\text { quality }\end{array}$} & Completeness & $\begin{array}{l}\text { "...many services are described very clear...", “....comprehensive information is provided... ", “...nice } \\
\text { photos make me influence..." }\end{array}$ \\
\hline & Relevance & $\begin{array}{l}\text { "...here I can get all information about assortment of leisure...", "you can click on Hotels menu and } \\
\text { find here all information about hotels..." }\end{array}$ \\
\hline & Easy to understand & "... usually it is easy to understand..." \\
\hline \multirow{2}{*}{ System quality } & Availability & $\begin{array}{l}\text { "...traditional payment is more convenient, than paying online..", “...I can pay here in cash, too a, and } \\
\text { it is more trustable..." }\end{array}$ \\
\hline & Reliability & $\begin{array}{l}\text { "...it is completely adopted to use it at home... ", "...I do it very quickly...”, "no problems arise... ”, “... } \\
\text { it makes me nervous, when site download delay..." }\end{array}$ \\
\hline \multirow{2}{*}{ Service quality } & Assurance & $\begin{array}{l}\text { "I know what to expect from } N \text { hotels, so I bought...”, “... as coupon is sold in advance I can manage } \\
\text { many vocation plans..." }\end{array}$ \\
\hline & Professionalism & $\begin{array}{l}\text { "...they provide everything for everyone...”, “...You can find here what you want”...”, “... } 100 \text { percent } \\
\text { guarantee is provided..." }\end{array}$ \\
\hline
\end{tabular}

\section{Results of Customers' Survey}

\section{Data of the Customers' Survey Characteristics}

A total number of the responses obtained were 103 out of which 81 (11\% males, $70 \%$ females) were valid and usable. Table 3 shows the summary of demographic profiles of the respondents. Although the sample size is relatively small, the respondents' experience in purchasing the leisure services coupons on group buying sites is high. Almost $30 \%$ of them stated more than three years of such experience and almost 57 $\%$ had experience of $1-2$ years. Almost $73 \%$ of the people said that they bought the leisure services coupons 2-5 times on group buying sites within last 12 months. Majority of respondents had positive experience with the online group buying for the leisure services coupons $(86.4 \%)$.
The research results show that the respondents bought a wide variety of the leisure services coupons within last 12 months (Table 4). The most common purchases were the coupons of beauty services and the coupons of adventure leisure services on group buying sites. This is quite understandable as most respondents were female. Every third respondent bought the coupons related to cultural events, catering, and accommodation services. The coupons, offered for children's games and entertainment services, were the least popular among respondents. The possible reason for such coupons' unpopularity might be the age of the respondents (young) and their family status (however, we did not researched).

Profile of the respondents $(\mathrm{N}=81)$

\begin{tabular}{|c|c|c|c|}
\hline Measure & Items & Frequency & Percent \\
\hline \multirow{2}{*}{ Gender } & Male & 11 & 13.6 \\
\hline & Female & 70 & 86.4 \\
\hline \multirow{3}{*}{ Age } & $18-24$ years old & 62 & 76.5 \\
\hline & 25-34 years old & 14 & 17.3 \\
\hline & Not indicated & 5 & 6.2 \\
\hline \multirow{2}{*}{ Education } & Secondary school & 60 & 74.1 \\
\hline & University and college & 21 & 25.9 \\
\hline \multirow{5}{*}{ Occupation } & Student & 44 & 54.3 \\
\hline & Student and employed & 23 & 28.4 \\
\hline & Employed & 10 & 12.3 \\
\hline & Self-employed & 2 & 2.5 \\
\hline & Other & 2 & 2.5 \\
\hline
\end{tabular}


Neringa Langviniene, Jurgita Zemblyte, Gelmine Sliziene. What Influences Buying Leisure Services Coupons on Online

\begin{tabular}{|c|c|c|c|}
\hline Measure & Items & Frequency & Percent \\
\hline \multirow{5}{*}{ Shopping experience of the leisure services coupons on OGB } & $<6$ months & 6 & 7.4 \\
\hline & $7-12$ months & 5 & 6.2 \\
\hline & $1-2$ years & 46 & 56.8 \\
\hline & 3-4 years & 19 & 23.5 \\
\hline & $>4$ years & 5 & 6.2 \\
\hline \multirow{3}{*}{ Frequency of buying the leisure services coupons on OGB within last 12 months } & 1 time & 19 & 23.5 \\
\hline & $2-5$ times & 59 & 72.8 \\
\hline & $6-10$ times & 3 & 3.7 \\
\hline \multirow{7}{*}{ Expenditure on the leisure services coupons on OGB within last 12 months } & $<20$ Euro & 11 & 13.6 \\
\hline & 21-50 Euro & 25 & 30.9 \\
\hline & 51-100 Euro & 26 & 32.1 \\
\hline & 101-150 Euro & 11 & 13.6 \\
\hline & 151-200 Euro & 4 & 4.9 \\
\hline & 201-250 Euro & 3 & 3.7 \\
\hline & $>250$ Euro & 1 & 1.2 \\
\hline \multirow{2}{*}{ Experience on OGB } & Positive & 70 & 86.4 \\
\hline & Negative & 11 & 13.6 \\
\hline \multirow{5}{*}{ Intention to buy the leisure services coupons on OGB next 12 months } & Yes, very much & 7 & 8.6 \\
\hline & Yes & 42 & 51.9 \\
\hline & Do not know & 24 & 29.6 \\
\hline & No & 2 & 2.5 \\
\hline & No, not at all & 6 & 7.4 \\
\hline
\end{tabular}

Table 4

The frequency of buying the leisure services coupons on group buying sites within last 12 months $(\mathrm{N}=\mathbf{8 1})$

\begin{tabular}{|l|c|c|}
\hline Leisure services & Number of times bought on group buying sites* & Percentage of respondents who bought \\
\hline Beauty services & 40 & 49.4 \\
\hline Adventure leisure services & 38 & 46.9 \\
\hline Culture events and activities services & 33 & 40.7 \\
\hline Food serving services & 33 & 40.7 \\
\hline Accommodation services & 32 & 39.5 \\
\hline Travel services & 25 & 30.9 \\
\hline Recreation and wellness services & 24 & 29.6 \\
\hline Amusement and theme parks service & 21 & 25.9 \\
\hline Sports and physical recreation services & 11 & 13.6 \\
\hline Courses and training & 9 & 1.1 \\
\hline Nightclubs, discos & 6 & 7.4 \\
\hline Camping services & 5 & 6.2 \\
\hline Children's games and entertainment services & 4 & \\
\hline Other services & 1 & \\
\hline
\end{tabular}

Note: * The respondent may buy the same leisure service several times within last 12 months.

We examined the relationships among demographic characteristics, experience of the respondents and the intention to buy the leisure service coupons on group buying sites during nearest future (Table 5). The analysis indicates that the respondents' intention to purchase the leisure services coupons on group buying sites depends on respondents' purchase frequency $(\mathrm{r}=0.282, \mathrm{p}<0.05)$, and respondents' group buying experience (Mann-Whitney $\mathrm{U}=146.5$, $\mathrm{p}<0.001)$. Those respondents, who have a long-term and positive experience on the leisure services coupons buying on group buying sites, are more likely to repeat their purchase using OGB in the future. One likely reason is that the respondents with experience are more informed and perceive online group buying more realistic. They are satisfied with group buying sites as well. In terms other demographic characteristics of respondents', the insignificant $(\mathrm{p} \geq 0.05)$ results for the effect of intention to buy on group buying sites are found.

Table 5

Correlation analysis of the intention to buy the leisure service coupons on group buying sites and respondents' demographic characteristics

\begin{tabular}{|c|c|c|c|c|}
\hline Variables & Spearman's rho & Mann-Whitney U & Person Chi-Square & Significance \\
\hline Gender & & 379.5 & & 0.934 \\
\hline Age & & 308.5 & & 0.065 \\
\hline Education & -0.078 & & & 0.490 \\
\hline Occupation & & & 4.343 & 0.362 \\
\hline Shopping experience of the leisure services coupons on OGB & -0.082 & & & 0.467 \\
\hline $\begin{array}{l}\text { Frequency of the leisure services coupons on OGB within last } \\
12 \text { months }\end{array}$ & -0.282 & & & $0.011^{*}$ \\
\hline $\begin{array}{l}\text { Expenditure on the leisure services coupons on OGB within } \\
\text { last } 12 \text { months }\end{array}$ & -0.156 & & & 0.163 \\
\hline Experience on OGB & & 146.5 & & $0.000 * *$ \\
\hline
\end{tabular}

Note: $*=$ sig. at $p<0.05, * *=$ sig. at $p<0.01$ 


\section{Influences, Affecting Customers' Purchase Intention towards Online Group Buying}

Altogether six influential factors were proposed, namely, price, trust, belonging to virtual community, system quality, information quality and service quality. The overall Cronbach's alpha reliability coefficient for 25 items was 0.757. It means that those items used in the questionnaire were satisfactory and acceptable for research purposes.

Correlation analysis was employed to evaluate the relationship between constructs in research model. Table 6 presents the Spearman's rho value for the relationship among variables. The correlation readings indicate significantly

weak to moderate $(r=0.23$ to 0.46$)$ positive correlation between information quality and trust; information quality and system quality; service quality and trust; service quality and system quality; service quality and information quality; negative correlation between information quality and belonging to virtual community; intention to buy and price. A deeper look into variables indicates that information quality has the most important positive relationship with system quality $(\mathrm{r}=0.46)$. Furthermore, relationship between intention to buy and price is significantly weak, negative $(\mathrm{r}=-0.23)$. On the other hand, other independent variables seem to make no significant ( $\mathrm{p} \geq 0.05)$ influence in customers' intention to buy the leisure services coupons on group buying sites.

Table 6

Inter-correlation analysis of influences and customers' intention to buy the leisure services coupons on group buying sites

\begin{tabular}{|l|c|c|c|c|c|c|}
\hline \multicolumn{1}{|c|}{ Variable No.: } & $\mathbf{1}$ & $\mathbf{2}$ & $\mathbf{3}$ & $\mathbf{4}$ & $\mathbf{5}$ & $\mathbf{6}$ \\
\hline 1. Price & 1.00 & & & & & \\
\hline 2. Trust & 0.03 & 1.00 & & & & \\
\hline 3. Belonging to virtual community & 0.09 & 0.06 & 1.00 & & & \\
\hline 4. System quality & 0.14 & -0.01 & 0.09 & 1.00 & & \\
\hline 5. Information quality & 0.17 & $0.24^{*}$ & $-0.23^{*}$ & $0.46^{* *}$ & 1.00 & \\
\hline 6. Service quality & -0.03 & $0.42^{* *}$ & 0.18 & $0.36^{* *}$ & $0.38^{* *}$ & 1.00 \\
\hline 7. Intention to buy & $-0.23^{*}$ & -0.05 & 0.01 & 0.00 & 0.13 & 0.09 \\
\hline & & & & & & \\
\hline Mean & 3.89 & 4.52 & 2.00 & 4.38 & 4.68 & 4.49 \\
\hline Std. Deviation & 0.78 & 0.47 & 0.90 & 0.57 & 0.40 & 0.51 \\
\hline
\end{tabular}

Note: $*=$ sig. at $p<0.05, * *=$ sig. at $p<0.01$

According to the correlation analysis results, as information quality score gets higher, system quality score $(r=0.46)$ and the trust score $(r=0.24)$ also increase; however, belonging to virtual community score $(r=-0.23)$ decreases. Thus, if group buying site provider presents better information, the need to communicate with friends, other people and to get recommendations becomes less important for customers. Furthermore, the research results have shown that service quality score gets higher, thus trust, information and system qualities scores increases too (resp. $r=0.42$, $r=0.38, r=0.36$ ). Hence, customers do expect good quality of services, physical or virtual care from the service provider. Group buying site provider's assurance, empathy, and responsiveness to customers seemed to increase the intention to buy on group buying site. Lastly, the relationships between intention to buy and price is statistically significant at $23 \%$ significance level and negative $(r=-0.23)$. Intention to buy score increases when price score decreases.

In this research, regression analysis has been applied with the aim of testing whether indicated influences have effect on intention to buy on group buying sites. The results of the hypotheses test are presented in Table 7.

The results revealed that only price significantly predicts intention to buy the leisure services coupons on group buying sites. Price was the strongest predictor $(\beta=-0.27$, $\mathrm{p}=0.02<0.05$ ). The negative sign of the $\beta$ value is due to the statements used to measure the price. Therefore, this result indicates that larger price is related to lower intention to buy on group buying sites - which is what we would expect. Then one unit increases in price, intention to buy decreases by 0.27 units $(\beta=-0.27, p=0.02)$. Thus hypothesis H1 was supported. Inconsistent with our expectations trust $(\beta=-0.15)$, information quality $(\beta=-0.13)$, service quality $(\beta=-0.11)$, system quality $(\beta=-0.07)$ and belonging to virtual community $(\beta=-0.01)$ were not significant predictors $(p \geq 0.05)$. More specifically trust, information quality, service quality, system quality and belonging to virtual community have a negative effect on online group buying intentions. Therefore, hypotheses H2, H3, H4, H5 and H6 were not supported. This reveals that online group buying intention cannot be predicted by these variables. Higher trust for the group buying provider will not influence to buy the leisure services coupons on group buying sites. The better system, service and information qualities are unrelated to customers' intention to buy on group buying sites as well. Furthermore, customers purchasing on OGB do not have positive attitude to membership in the virtual community, social networks.

Results of hypothesis testing

\begin{tabular}{|c|c|c|c|c|}
\hline Hypotheses & $\begin{array}{c}\text { Standardized } \\
\text { coefficient Beta }\end{array}$ & $t$-value & $\begin{array}{c}\text { Significance } p \text { - } \\
\text { value }\end{array}$ & Result \\
\hline H1: Price $\rightarrow$ Intention to buy & -0.27 & -2.44 & $0.02 *$ & Supported \\
\hline H2: Trust $\rightarrow$ Intention to buy & -0.15 & -1.37 & 0.18 & Not supported \\
\hline H3: Belonging to virtual community $\rightarrow$ Intention to buy & -0.01 & -0.04 & 0.97 & Not supported \\
\hline H4: System quality $\rightarrow$ Intention to buy & -0.07 & -0.58 & 0.56 & Not supported \\
\hline H5: Information quality $\rightarrow$ Intention to buy & -0.13 & -1.15 & 0.25 & Not supported \\
\hline H6: Service quality $\rightarrow$ Intention to buy & -0.11 & -0.98 & 0.33 & Not supported \\
\hline
\end{tabular}

Note: $*=$ sig. at $p<0.05$ 


\section{Discussion and Conclusions}

This study examines the influences on the customers' decision to buy or not the leisure services coupons on group buying sites. Previous research has successfully proved that price, trust, belonging to virtual community, system quality, information quality and service quality are significant to predict customers' intention to purchase on OGB. Our findings partly support the appropriateness of such variables. Only price has weak effect in turn on customers' decisions to purchase on group buying sites. However, in contrast to the results of most studies, trust, belonging to virtual community system quality, information quality and service quality were shown not effecting customers' intention to buy on group buying sites.

The importance of price shows that the customers on OGB are very oriented to price and discounts. There are several explanations for this. First, most of our respondents were very experienced in OGB, purchase diversity of the leisure services coupons, but they spent not more than 100 Euros within last year. Second, the model of OGB was the "deal of the day". According to Erdogmus and Cicek (2011), OGB sites are commonly oriented to price-sensitive customers, who enjoy price discounts. Hence, customer visiting such group buying sites expects lower prices as such and hopes to save money. However, customers are not highly sensitive to price changes. The main customers' preference to purchase on online group buying based on price was identified by Abdul-Muhmin (2011), Chen (2012), Shiau and Luo (2012), Cheng and Huang (2013). Fan et al. (2010) also identified a price as going ahead to all other factors. Thus, our finding is consistent with prior studies.

Our empirical result showed that higher trust for group buying site provider would not influence to buy the leisure services coupons on group buying sites. In contrary to the result that trust is insignificant in intentions to buy on group buying sites, our findings indicate that the customers' expectations of trust are very high (mean $=4.53$, see Table 7). We offer possible reasons. First, the largest part of respondents buys on well-known group buying sites (see Table 1). Previous research has shown that most online customers trust larger companies more than small (Ling et al., 2010). Second, the almost $90 \%$ customers have positive experience on group buying sites (see Table 3). A positive customers' experience with online group buying creates trust. Our research result is contrary to the prior literature, which found that trust in the virtual community is one of main factors (Pi et al., 2011), trust exerted a stronger effect than perceived price (Kim et al., 2012b) on customers' intentions to buy on online group buying. In addition, Shiau and Luo (2012) founded, that online group buying is predicted by trust, and by collective purchases, by customer satisfaction and seller creativity.

The analytical results demonstrate a significant and positive correlation among information quality, service quality and trust. Therefore, the online group buying site provider seeking to gain customers' trust has to focus on designing both information on websites and customer focus. Thus, the attention must be paid to virtual and physical care.

Furthermore, customers buying on OGB do not have positive attitude towards membership in the virtual community on OGB. This can be explained that researched customers are not interested in connection with other members, knowledge and experience sharing with other customers. This is contrary to the finding that social interaction appears to be important for OGB (Tsai et al., 2011). The sense of virtual community has significant effect on OGB intention was found by Cheng et al. (2012) as well. In addition, Azam and Qiang (2012) found that familiarity with other purchasers in the same sites has strong influence on OGB. However, in the case of OGB, we have not observed that virtual community matters. It is possible that the group buying model ("deal of the day"; the specific amount of the service are offered with discount) do not require customers to control how many coupons are sold and belong to community. Thus, single customer is not so important in order to get discount. The ignorance of virtual community also might be caused by the fact that the most respondents buy beauty care, cultural and other daily leisure services, consumed not far from home (see Table 4). Thus, there is no need for the specific information or advice of professionals.

In terms of relationships among system, information, service qualities and intention to buy on group buying sites, we found no support. Service quality is not the crucial factor to influence a shopper purchase. As it was found out in our research, the system, information and service qualities correlate (see Table 6). The better perception of service quality increases perception of information and system qualities. Hence, group buying sites operators' accuracy, empathy, responsiveness and ability to solve problems affect other quality aspects. The insignificance of system, information and service qualities on intention to buy is contrary only to the findings in prior research. Cheng and Huang (2013) discovered that system quality attitude positively affects intention, and intention positively affects online group-buying behaviour. Website quality and online retailer quality have significant positive effect on OGB intention (Chen et al., 2013). The finding by Corbitt et al. (2003) showed that the larger evaluation of quality of the service, the larger trust for the provider was founded.

Considering demographic characteristics and experience of the respondents, the results indicate that the customers' intentions to purchase the leisure services coupons on group buying sites depends on purchase frequency and group buying experience (positive/negative). Other demographic characteristics are insignificant. This is consistent with finding of Corbitt et al. (2003) where e-commerce customers own experience and attitudes influencing their decisionmaking process. Similarly, Chen et al. (2013) found that experience of OGB had significant positive effect on OGB intention. Hsu et al. (2014) proved that customers' positive experience, in terms of satisfaction, affected the intention to group buying. Moreover, Shiau and Luo (2012) confirmed that satisfaction with seller and with website have positive influence on repurchase intention.

Overall, the findings what influences buying on OGB of the sampled respondents mostly differ from earlier results by different research. Here a specific in choosing the leisure services coupons on group buying sites occurs. These findings provide insights into how customers' decision to buy or not the leisure services coupons on group buying sites might be influenced. 
This research has certain limitations. The approach of the research might be considered narrow enough in the terms of generalization, regarding customers' intention to buy the leisure service coupons on group buying sites. We cannot draw any significant conclusions that would refer to all customers. The research respondents' sample was students with small variances in age and education, which are variables that can influence the intention to use OGB. Instead of using students as sample, future research could consider more representative sample of OGB customers. Customers from different age, gender and income groups might have different perception of OGB. Furthermore, our results based on quite experienced customers, thus potential customers' opinion about influences to buy on group buying sites might be useful. Moreover, it was one time study in April 2015; the respondents' criteria for online group buying might change. It is necessary for longitudinal survey. Nevertheless, the research has developed our understanding of intentions to buy the leisure service coupons on group buying sites from customers' viewpoint.

\section{Appendix}

\section{Questionnaire items}

\begin{tabular}{|c|c|}
\hline Construct & Items \\
\hline \multirow{2}{*}{ Price } & I buy on group buying site because it provides desired leisure services lower price or discounts. \\
\hline & I buy on group buying site because I can find unknown leisure services for the best, lower price. \\
\hline \multirow{4}{*}{ Trust } & Group buying site has the necessary skills and ability to carry out online transaction precise, consistent and stable. \\
\hline & Group buying site gives me a feeling of trust and confidence. \\
\hline & Group buying site provides only valid leisure services' coupons and leisure services that company is capable to provide. \\
\hline & Group buying site has good reputation and image. \\
\hline \multirow{4}{*}{$\begin{array}{l}\text { Belonging to virtual } \\
\text { community }\end{array}$} & I usually consult with my Facebook friends about the leisure services coupons provided by group buying site. \\
\hline & Buying on group buying site I do not feel lonely, as I see a group of buyers buying the same leisure services coupon. \\
\hline & Buying on group buying site I can control, observe the number of buyers who buy the same leisure services coupons. \\
\hline & $\begin{array}{l}\text { Buying on group buying site I feel I am important as desired leisure services coupons will be valid if acquire relevant number } \\
\text { of buyers. }\end{array}$ \\
\hline \multirow{6}{*}{ System quality } & Group buying site works without failure 24/7. \\
\hline & Group buying site is easy to use. \\
\hline & It is easy to find information on group buying site. \\
\hline & It is easy to buy on group buying site; data transmission is unobstructed. \\
\hline & Group buying site is functional (graphical dialog boxes, icons, menus, lists, etc.). \\
\hline & Group buying site opens quickly and easily. \\
\hline \multirow{4}{*}{ Information quality } & Group buying site provides in-depth information about prices, discounts, leisure services description, service companies, etc. \\
\hline & Group buying site provides up-to-date information about the leisure services coupons. \\
\hline & Group buying site provides useful and sufficient information about the leisure services coupons. \\
\hline & Group buying site provides accurate information about the leisure services coupons. \\
\hline \multirow{4}{*}{ Service quality } & Group buying site provides security and privacy protection. \\
\hline & Group buying site exhibits willingness to help customers. \\
\hline & Group buying site shows a sincere interest in solving customer problems. \\
\hline & Group buying site shows professionalism in answering customer questions. \\
\hline Intention to buy & $\begin{array}{l}\text { I am likely to buy on group buying sites within the next } 12 \text { months } \\
\text { (Yes, very much; Yes; I don't know; No; No, not all) }\end{array}$ \\
\hline
\end{tabular}

Note: all items used a five-point Likert-type scales from 1 (strongly disagree) to 5 (strongly agree)

\section{References}

Abdul-Muhmin, A. G. (2011). Repeat purchase intentions in online shopping: the role of satisfaction, attitude, and online retailers' performance. Journal of International Customer Marketing, 23, 5-20. DOI: 10.1080/08961530.2011.524571.

Azam, A., \& Qiang, F. (2012). An economic model of the customers' online shopping utility and factors affecting on online shopping. International Journal of Computer Applications, 55 (1), 24-31. http://dx.doi.org/10.5120/8166-1406

Bagdoniene, L., \& Zemblyte, J. (2009). Online shopping motivation factors and their effect on Lithuanian Customers. Economics \& Management, 14, 367-374.

Brengman, M., \& Karimov, F. P. (2012). The effect of web communities on customers' initial trust in B2C e-commerce websites. Management Research Review 35 (9), 791-817. http://dx.doi.org/10.1108/01409171211256569

Chang, M. K., Cheung, W., \& Lai, V. S. (2005). Literature derived reference models for the adoption of online shopping. Information and Management, 42 (4): 543-60. DOI: 10.1016/j.im.2004.02.006.

Chang, S. C., Chou, P. Y., \& Lo, W. C. (2014). Evaluation of satisfaction and repurchase intention in online food groupbuying, using Taiwan as an example. British Food Journal, 116 (1), 44-61. http://dx.doi.org/10.1108/BFJ-03-20120058

Chen, C. P. (2012). Online group buying behavior in CC2B e-commerce: Understanding Customer Motivations. Journal of Internet Commerce, 11, 254-270. DOI: 10.1080/15332861.2012.729465.

Chen, K., Wang, X., Zheng Q., \& Luo, H. (2013). An exploratory study of influence factors about customers' online group buying intention. Journal of Applied Sciences, 13, 1370-1375. http://dx.doi.org/10.3923/jas.2013.1370.1375 
Cheng, H. H., \& Huang, S. W. (2013). Exploring antecedents and consequence of online group-buying intention: An extended perspective on theory of planned behaviour. International Journal of Information Management, 33, $185-198$. DOI: 10.1016/j.ijinfomgt.2012.09.003.

Cheng, H. H., Tsai, M. T., Cheng, Ch., \& Chen K Sh. (2012). Predicting intention to purchase on group buying website in Taiwan: virtual community, critical mass and risk. Online Information Review, 36 (5), 698-712. DOI: $10.1108 / 14684521211275984$.

Community survey on ICT usage in households and by individuals (2015). Eurostat Statistics Explained. http://ec.europa.eu/eurostat/statistics-

explained/index.php/Glossary:Community_survey_on_ICT_usage_in_households_and_by_individuals.

Corbitt, B. J., Thanasankit, T., \& Yi, H. (2003). Trust and e-commerce: a study of customer perceptions. Electronic Commerce Research and Applications, 2, 203-215. DOI: 10.1016/S1567-4223(03)00024-3.

Crespo, A. H., \& Bosque, I. R. (2008). The effect of innovativeness on the adoption of B2C e-commerce: A model based on the Theory of Planned Behavior. Computers in Human Behavior, 24, 2830-2847. DOI: 10.1016/j.chb.2008.04.008.

Erdogmus, I. E., \& Cicek, M. (2011). Online group buying: What is there for the customers? Procedia Social and Behavioural Sciences, 24, 308-316. DOI: 10.1016/j.sbspro.2011.09.138.

Fan, Y. W., Chiang, M. H., Wang, J. Y., \& Wang. E. T. G. (2010). A study on customers' continuing to use online groupbuying platforms: The impact of price performance expectations. Chinese Business Review, 9 (12), 44-52.

Gefen, D., \& Straub, D. W. (2004). Customer trust in B2C e-commerce and the importance of social presence: experiments in e-products and e-services. Omega, the International Journal of Management Science, 32, 407-424. DOI: 10.1016/j.omega.2004.01.006.

Harris, K. E., Mohr, L. A., \& Bernhardt, K. L. (2006). Online service failure, customer attributions and expectations. Journal of Services Marketing, 20 (7), 453-458. DOI: 10.1108/08876040610704883.

Hernandez, B., Jimenez, J., \& Martin, M. J. (2010). Customer behavior in electronic commerce: the moderating effect of epurchasing experience. Journal of Business Research, 63, 964-971. DOI: 10.1016/j.jbusres.2009.01.019.

Hsu, M.H., Chang, C.M., Chu, K.K., Lee, Y.J. (2014). Determinants of repurchase intention in online group-buying: The perspectives of DeLone \& McLean IS success model and trust. Computers in Human Behavior, 36, 234-245. DOI: 10.1016/j.chb.2014.03.065.

Huang, Y. F., \& Kuo, F. Y. (2012). How impulsivity affects customer decision-making in e-commerce. Electronic Commerce Research and Applications, 11, 582-590. DOI: 10.1016/j.elerap.2012.09.004.

Iglesias-Pradas, S., Pascual-Miguel, F., Hernandez-Garcia, A., \& Chaparro-Pelaez, J. (2013). Barriers and drivers for nonshoppers in B2C e-commerce: A latent class explanatory analysis. Computers in Human Behavior, 29, 314-322. DOI: 10.1016/j.chb.2012.01.024.

Informacines visuomenes statistika. Namu ukiai ir asmenys (2015). Papildoma Eurostato informacija. Pagrindines lenteles ir duomenu baze. http://ec.europa.eu/eurostat/statistics-explained/index.php/Information_society_statistics__households_and_individuals/lt.

Kim, C., Galliers, R. D., Shin, N., Ryoo, J. H., \& Kim, J. (2012a). Factors influencing internet shopping value and customer repurchase intention. Electronic Commerce Research and Applications, 11, 374-387. DOI: 10.1016/j.elerap. 2012.04.002.

Kim, H. W., Xu, Y., \& Gupta, S. (2012b). Which is more important in internet shopping, perceived price or trust? Electronic Commerce Research and Applications, 11, 241-252. DOI: 10.1016/j.elerap.2011.06.003.

Langviniene, N. (2013). Laisvalaikio paslaugu vaidmuo gyvenimo kokybes kontekste: mokslo studija. Kaunas: Technologija. DO 10.5755/e1.9786090208366.

Langviniene, N., \& Guobyte, V. (2014). Online group buying factors - conceptual model for understanding customer value. Social Sciences, 84 (2), 21-28. DOI: 10.5755/j01.ss.84.2.7485.

Ling, K. C., Chai, L. T., \& Piew, T. H. (2010). The effects of shopping orientations, online trust and prior online purchase experience toward customers' online purchase intentions. International Business Research, 3 (3), 63-76. DOI: 10.5539/ibr.v3n3p63.

Mazaheri E., Richard, M. O., \& Laroche, M. (2012). The role of emotions in online customer behavior: a comparison of search, experience, and credence services. Journal of Services Marketing, 26 (7), 535-550. DOI: 10.1108/ 08876041211266503.

Munzel, A., \& Kunz, W. H. (2014). Creators, multipliers, and lurkers: who contributes and who benefits at online review sites. Journal of Services Management, 25 (1), 49-74. DOI: 10.1108/JOSM-04-2013-0115.

Pai, P. Y., \& Tsai, H. T. (2011). How virtual community participation influences customer loyalty intentions in online shopping contexts: an investigation of mediating factors. Behaviour \& Information Technology, 30 (5), 603-615. DOI: 10.1080/0144929X.2011.553742. 
Parboteeach, D. V., Valacich, J. S., \& Wells, J. D. (2009). The influence of website characteristics on a customer's urge to buy impulsively. Information Systems Research, 20 (1), 60-78. DOI: 10.1287/isre.1070.0157.

Pi, S. M., Liao, H. L, Liu, S. H., \& Lee, I. S. (2011). Factors influencing the behaviour of online group-buying in Taiwan. African Journal of Business Management, 5 (16), 7120-7129. DOI: 10.5897/AJBM10.1395.

Shiau, W.L., \& Luo, M. M. (2012). Factors affecting online group buying intention and satisfaction: A social exchange theory perspective. Computers in Human Behaviour, 28 (6), 2431-2444. DOI: 10.1016/j.chb.2012.07.030.

Sigala, M. (2013). A framework for designing and implementing effective online coupons in tourism and hospitality. Journal of Vacation Marketing, 19, 165-180. DOI: 10.1177/1356766712471839.

Swinyard, W. R., \& Smith, S. M. (2011). Activities, interests, and opinions of online shoppers and non-shoppers. International Business and Economics Research Journal, 3 (4), 37-48. http://dx.doi.org/10.19030/iber.v3i4.3680

Tsai, M. T., Cheng, N. C., \& Chen, K. S. (2011). Understanding online group buying intention: the roles of sense of virtual community and technology acceptance factors. Total Quality Management, 22 (10), 1091-1104. DOI: 10.1080/14783363.2011.614870.

Yin, L., \& Liu, L. (2012). A conceptual model for investigating online group buying in virtual communities. Advances in Information Sciences and Service Sciences, 4 (8), 19-26. DOI: 10.4156/AISS.vol4.issue8.3.

The article has been reviewed.

Received in August, 2015; accepted in June, 2016. 